\title{
TREATMENT OF WASTEWATERS OLIVE MILL BY ELECTROCOAGULATIONAND BIOLOGICAL PROCESS
}

\author{
M. Neffa \\ H. Hanine \\ B Lekhlif \\ M. Taourirt \\ K Habbari \\ Université of Sultan Moulay Slimane, FST, Beni Mellal, Morrococ. \\ Centre of study of sciencess of Ressources of water (CERHYDREAU), \\ School of Hassania ofpublic works (EHTP) Casablanca-Morroco.
}

\begin{abstract}
Olive mill wastewaters (OMWW) cause a recurrent environmental pollution problem. Treatment and reuse of olive mill wastewater (OMWW) presents significant challenges both due to the nature of olive oil production (seasonal and small scale) and due to the characteristics of the wastewater (high chemical oxygen demand (COD) and high phenolic content in the organic fraction of OMWW principally responsible for the phytotoxicity and microbial growth inhibitory effects of the effluent). In the present work the combined pretreatment of actual olive mill wastewaters by electrocoagulation and coagulation with natural organic coagulant, such as TNN and Kim 2212, and the biological purification, was investigated. Tests were conducted with raw OMWW and diluted with tap water at $\mathrm{pH}$ neuter adjusted by adding lime coagulant with chemical oxygen demand (COD) contents of $178 \mathrm{~g}$ d'O2.1-1, total suspended solids (TSS) of $6,4 \mathrm{~g} / \mathrm{L}$, Conductivity (mS.cm-1) of $29, \mathrm{pH}$ of 4,8 and turbidity of 50 NTK. The optimum removal of COD, turbidity and total polyphenolic was respectively $38,39 \%, 74,45 \%$ and $60 \%$. This results was obtained with TNN coagulation at $\mathrm{pH}(7)$ and $20 \mathrm{mg} / 1$ of the coagulant. The maximum organic matter removals by electrocoagulation $\left(56.76 \%\right.$ ) processes was achieved after $90 \mathrm{~min}$, by using $15 \mathrm{~V} / \mathrm{m}^{2}$ voltage kept constant for each run at initial $\mathrm{pH}$ of the OMWW $(4,4)$.

Olive mill wastewater (OMWW) was then treated aerobically with fungi.

The results show that the fungus is capable of reducing chemical oxygen demand $68 \%$ and $75 \%$ for the diluted OMWW at $50 \%$ treated by lime and lime/KIM 2120 respectively, after only 5 days of growth. Neutral $\mathrm{pH}$ seems supported aerobic treatment.
\end{abstract}

\section{KEYWORDS}

OMWW, electrocoagulation, COD, KIM, polyphenolic compounds,

\section{INTRODUCTION}

Olive oil industrie are of fondamental economic importance for may Mediterranean contries et particulary at Morroco . That account for approximately $95 \%$ of the wordwide olive oil production. Olive mill wastewater ( OMWW) is bye product of olive oil extraction process in large volume $(0.5-0.8 \mathrm{~m} 3) /$ tones of olive fruits treated $(1)$. In the olive growing contriers of

https://doi.org/10.15626/Eco-Tech.2010.031 
the mediteranean area ( Greece, Italy, Spain and Morroco, Tunis) olive oil mill effluent production is more than 30 millions $\mathrm{m} 3$ per year (2). The three main producer countries spain, Italy and Greece are closely followed bye Syria, Turkey and Tunisia. The contribution of other countries such as Morroco Portugal, Algeria Jordan, Palestine Argentine Lebanon France Libya Israel and Cyprus is much lower. Olive mill wastes water are significant source of potential or existing environnemental pollution in these countries

The wastewater from olive oil production is characterized bye the following special features and components (3)

High degree of organic pollution (COD) values up to $220 \mathrm{~g} / 1$ at a COD/BOD5 ratio 2.5 and 5 pH between 3-5.9 ( slightly acidic)

High content of polyphenolic compounds $(>80 \mathrm{~g} / 1)$

High content of solid matter $(>20 \mathrm{~g} / \mathrm{l})$

The environnemental impact of OMWW is considerable with the dangereous effects, such as coloring of natural waters, threat to the aquatic life causing surface and ground water pollution, changing soil quality and plant growth and causing odors.

The difficulties of treatment of olive mill effluents are mainly related to high organic loading, seasonal operation, high territorial scattering and presence of organic compounds which are hard to biodegradable, such as long chain fatty acids and phenolic compounds.

Many different processes have been proposed to trent the OMWW lagooning or direct watering on fields, co-composting physic-chemical methods ( floculation, coagulation, filtration, open evaporation ponds and incineration) ultrafiltration, reverse osmotic, chemical and electrochemical treatments and manufacture into animal food. Biological methods used for OMWW treatment are aerobic activated sludge and anaerobic digestion. Because of their antibacterial effects, phenolic compounds are the main drawback to OMWW degradation by aerobic process.

Recent research has demonstrated that electrochemical process offers an attractive alternative to traditional methods for treatment wastewater and also flue gases. The electrochemical oxidation of phenol present in the olive oil mill wastewater on alginate, carbon electrodes (4) on several metals oxide electrode (6) and on electro activated carbon granules (5) was investigated for the goal of treating wastewater. Treatment og OMWW by an electrochemical method was studied on several anode materials and on $\mathrm{Al}$ and Fe electrodes in a parallel plate arrangement (6) .

Electrocoagulation is one of the simple and efficient electrochemical method for the purification on many type of water and wastewater. It is based on the fact that the stability of colloides, suspensions and emulsions is influenced by electric charge of the particles is neutralized and several particles combine into larger and separable agglomerate (7).

During electrocoagultation, when a potential difference is applied between a soluble anode, such as $\mathrm{Fe}$ or $\mathrm{Al}$ and the cathode, ferrous or aluminium ions form at the anode and hydroxyl ions are generated at the cathode. This process is followed by in situ oxidation to the ferric state and subsequent precipitation as ferric or aluminium hydroxide. It is known that the hydrolysis products of $\mathrm{Al} 3+$ and $\mathrm{Fe} 2+$ are responsible for the effects observed during particle aggregation (8) .

In this study, treateability of olive mill wastewater by electrocoagulation using different floculant and aluminum with addition of some extract such as, Kim and Calcium hydroxide, Alginate that would feasible and economic in use for small and mid size facilities were investigated.

\section{MATERIALS AND METHODS}

\subsection{OMW used}


The original wastewaters used in the present study were obtained from an olive oil production plant located in the city of Beni Mellal between the Middle Atlas mountains and the plain of Tadla, in the coordinates ( $32^{\circ} 20^{\prime} 22^{\prime \prime} \mathrm{N}, 6^{\circ} 21^{\prime} 39^{\prime \prime} \mathrm{W}$ ) in central Morocco, which uses a (three phases) continuous process for extraction of olive oil. OMW was stored in a closed plastic container at ambient temperature

The Table 1 shows the physicochemical characteristics of the raw OMW used and diluted with tap water.

Table 1.Physico-chemical characteristics of fresh and diluted olive mill wastewaters with tap water.

\begin{tabular}{lrrrrr}
\hline \multicolumn{1}{c}{ Parameter } & $\begin{array}{r}\text { Valeur } \\
\text { moyenne }\end{array}$ & $\begin{array}{r}\text { Dilution } \\
\text { D4 }(20 \%)\end{array}$ & $\begin{array}{c}\text { Dilution } \\
\text { D3 }(30 \%)\end{array}$ & $\begin{array}{r}\text { Dilution D2 } \\
(40 \%)\end{array}$ & $\begin{array}{r}\text { Dilution } \\
\text { D1 (50\%) }\end{array}$ \\
pH & 4,8 & 4,89 & 4,89 & 4,9 & 4,9 \\
Turbidity (NTU) & 50 & 69 & 76 & 83 & 90 \\
Total suspended solid (g.1-1) & 6,4 & 5,15 & $* * * * * *$ & $* * * * *$ & 3,22 \\
$\begin{array}{l}\text { chemical oxygen demand } \\
\text { (COD) }\end{array}$ & 178 & 176 & 153 & 144 & 112 \\
$\begin{array}{l}\text { (g d'O2.1-1) } \\
\text { Conductivity (mS.cm-1) }\end{array}$ & 29 & 28,6 & 21,6 & & 19,8 \\
\hline
\end{tabular}

\subsection{Physical-chemical analysis of OMWW}

A digital calibrated pH-meter (JENCO 6230) and a conductivity-meter (ORION 125) were used to measure the $\mathrm{pH}$ and the conductivity of the OMW wastewater samples. Total and dissolved chemical oxygen demand (COD) was determined by spectrophotometer method A spectrophotometer (UV-vis PALINTEST 7000) was used for the photometric COD. The turbidity was measured with a turbidimeter (ORBECO-HELLIGE).

Total suspended solid (TSS) was determined after filtering a sample through a GF/C filter $(0.45 \mu \mathrm{m})$ and drying the retained residue at $105^{\circ} \mathrm{C}$ for $4 \mathrm{~h}$.

\subsection{Electrocoagulation procedure}

\section{A brief description of EC using aluminum electrodes}

Electrocoagulation is a process consisting of creating a floc of metallic hydroxides within the effluent to be treated by electrodissolution of a soluble anode. The coagulant in this technique is mentioned in situ by dissolution of a sacrificial anode and it involves three main processes [9, 10]: electrolytic reaction at electrode surface, formation of coagulants by electrolytic oxidation in aqueous phase and adsorption of colloidal particles on coagulant, and removal by sedimentation or flotation. It is well known that in EC process the main reactions occurring at the aluminum electrodes during electrolysis are:

At the anode:

$$
\begin{aligned}
& \mathrm{Al}_{(\mathrm{s})} \rightarrow \mathrm{Al}^{3+}{ }_{(\mathrm{aq})}+3 \mathrm{e}^{-} \\
& 2 \mathrm{H}_{2} \mathrm{O} \rightarrow \mathrm{O}_{2}+4 \mathrm{H}^{+}+4 \mathrm{e}^{-}
\end{aligned}
$$


At the cathode:

$$
3 \mathrm{H}_{2} \mathrm{O}(\mathrm{l})+3 \mathrm{e}^{-} \rightarrow \frac{3}{2} \mathrm{H}_{2}+3 \mathrm{OH}^{-}
$$

In the solution:

$$
\mathrm{Al}^{3+}{ }_{(\mathrm{aq})}+3 \mathrm{H}_{2} \mathrm{O} \rightarrow \mathrm{Al}(\mathrm{OH})_{3(\mathrm{~s})}+3 \mathrm{H}^{+}(\mathrm{aq})
$$

Species can interact in solution in several ways: (Eq. (1)) Migration to an oppositely charged electrode (electrophoresis) and aggregation due to charge neutralization. When the anode potential is sufficiently high, secondary reactions may occur, especially oxygen evolution (Eq. (2)). The cation or hydroxylion $\left(\mathrm{OH}^{-}\right)$forms a precipitate with the pollutant (Eq. (3)). The metal ions generated are hydrolyzed in the electrochemical cell to produce metal hydroxide ions according to reaction (Eq. (4)). The $\mathrm{Al}^{3+}$ and $\mathrm{OH}^{-}$ions produced at the electrodes can react to form variousmono-nuclear $\left(\mathrm{Al}(\mathrm{OH})_{2}{ }^{+}, \mathrm{Al}(\mathrm{OH})_{2}{ }^{+}, \mathrm{Al}_{2}(\mathrm{OH})_{2}{ }^{4+}\right)$ and poly-nuclear $\left(\mathrm{Al}_{6}(\mathrm{OH})_{15}{ }^{3^{+}}, \mathrm{Al}_{7}(\mathrm{OH})_{17}{ }^{4+}, \mathrm{Al}_{8}(\mathrm{OH})_{20}{ }^{4+}, \mathrm{Al}_{13}(\mathrm{OH})_{34}{ }^{5+}, \mathrm{Al}_{13} \mathrm{O}_{4}(\mathrm{OH})_{24}{ }^{7+}\right)$ species, which are finally transformed into aluminium hydroxide: $\mathrm{Al}(\mathrm{OH})_{3}$. The large specific area of $\mathrm{Al}(\mathrm{OH})_{3}$ then facilitates compound adsorption and traps the colloids $(9,10)$. Finally, these colloid-adsorbed floc can be removed by sedimentation or by floatation with $\mathrm{H}_{2}$ bubbles produced at the cathode.

\subsection{Experimental procedures}

Experiments were carried out in a jar-test apparatus (Figure1a and, 1b) equipped with six beakers of $1 \mathrm{~L}$ volume. At the beginning of each experiment, the OME samples were analysed with respect to their initial TSS, dissolved COD, $\mathrm{pH}$, turbidity. The initial $\mathrm{pH}$ of the solutions was adjusted by adding lime coagulant; six different appropriate dosages of both coagulants (alginate (TNN) and Kim 2120) were applied. Following (20 s) of rapid mixing and $30 \mathrm{~min}$ of slow mixing periods to facilitate floc agglomeration, The sample was then left and as soon as separation was achieved, the supernatant was analysed.

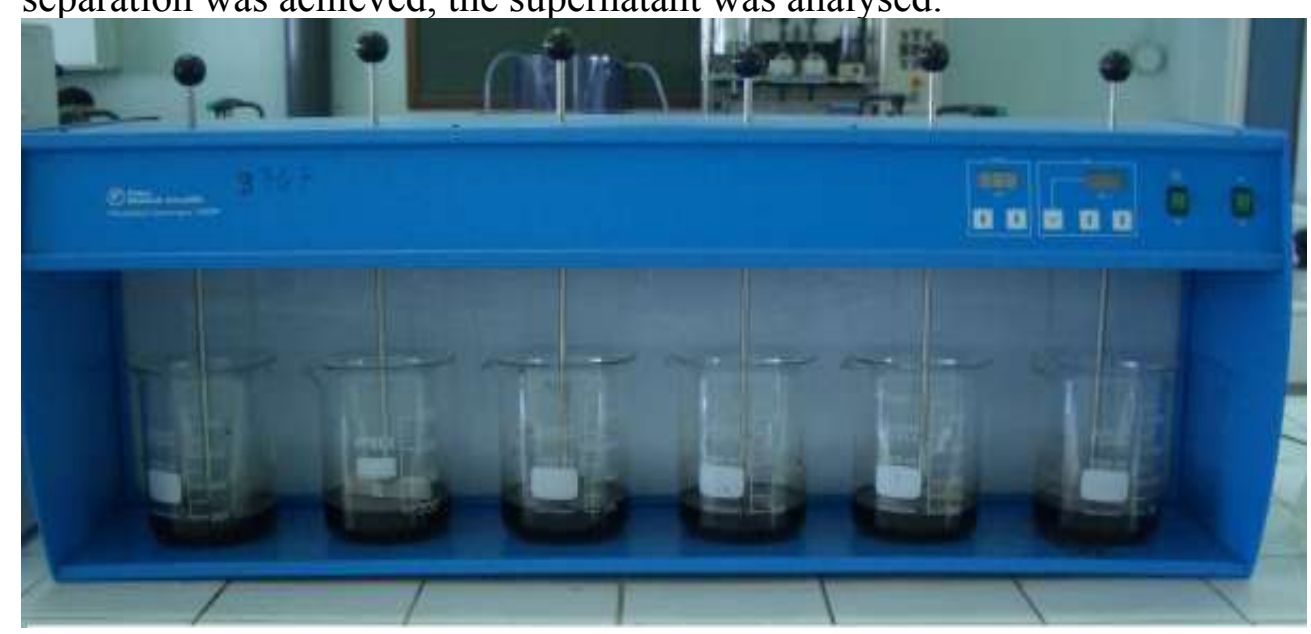

Figure.1a: optimization of the coagulation process using a Jartester 




Figure.1b. Overview of an electrocoagulation cell with two aluminum electrodes

The electrocoagulation experiments were carried out using two parallel aluminum electrodes $\left(\mathrm{S}_{\text {тЕ }} 4,5 \mathrm{~cm}^{2} \times 2\right.$ face) The anode/cathode gap was kept constant at $2 \mathrm{~cm}$. For each run, 100 $\mathrm{cm}^{3}$ of different dilution of OMWW were placed into the electrolytic cell. A gentle magnetic stirring rate of about $200 \mathrm{rpm}$ was applied to the electrolyte in all tests to allow the chemical precipitate to grow large enough for removal (with a stir bar of $\varnothing 6 \mathrm{~mm} \times 15 \mathrm{~mm} \mathrm{lenth}{ }^{2}$ ). The voltage $(15 \mathrm{~V})$ was kept constant for each run. Thereafter, the samples were decanted for $24 \mathrm{~h}$ before being subjected to vacuum filtration through filters with a pore size of $0.45 \mu \mathrm{m}$. In the sample filtrated: COD, Total suspended solid (TSS), $\mathrm{pH}$, turbidity were measured. The total time duration of electrolysis was $180 \mathrm{~min}$ for most test runs. [S $\mathrm{S}_{\mathrm{TE}}$ effective area of electrode]

\section{RESULTS AND DISCUSSION}

\subsection{Treatment by coagulation-flocculation}

Preliminary tests were performed to assess the relative efficiency of various coagulants to destabilized OMWW at different dilution (figure.2) 


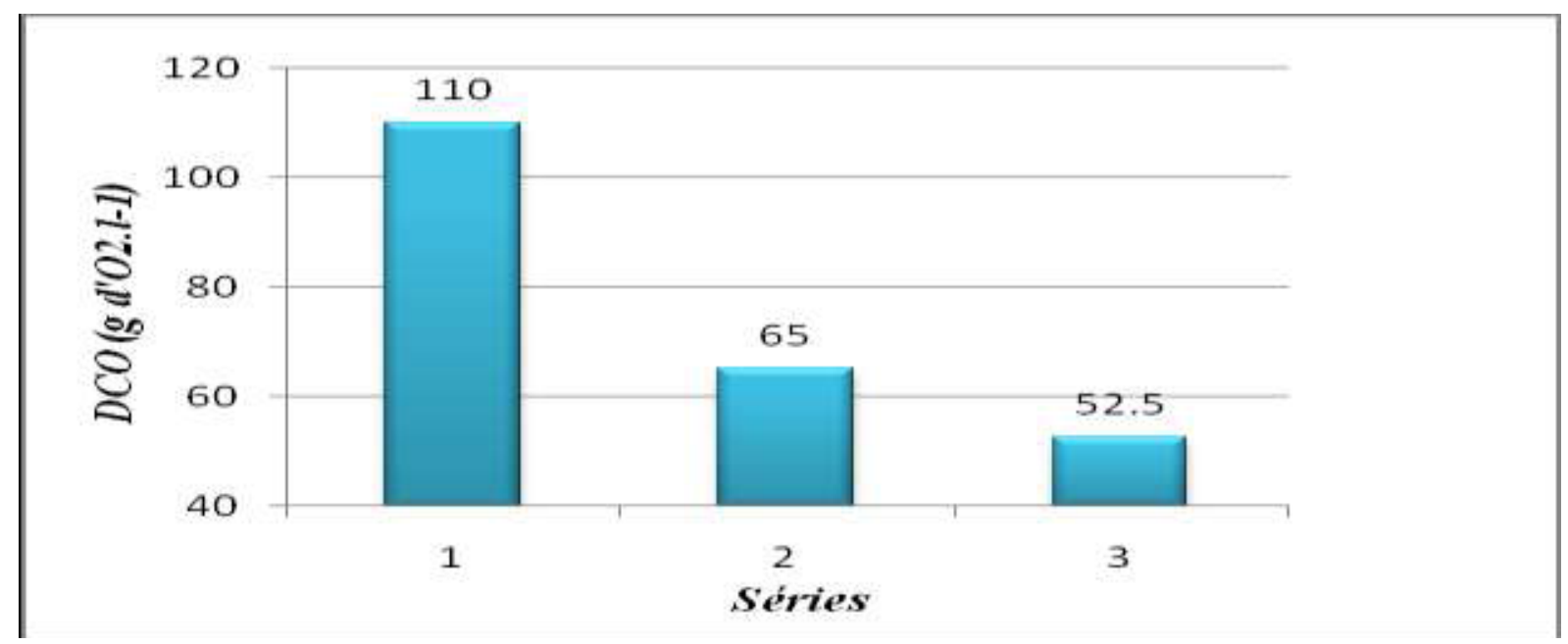

Figure2. Evolution of COD according to the type of flocculant for a OMW vegetable diluted $50 \%$

We found that after coagulation-flocculation of vegetable, either by adding alginate or Kim2120, the COD decreases. However treatment with the complex Lime / alginate results in a percentage reduction of COD by $41 \%$, while the Lime / Kim 2120 , it is about $52 \%$. This result is consistent with Mendia and Procino (1964) and Beccariet al. (1999) who obtained a COD reduction of $40-50 \%$ using lime.

\subsubsection{Comparison of the effect of coupling lime with various natural organic coagulants}

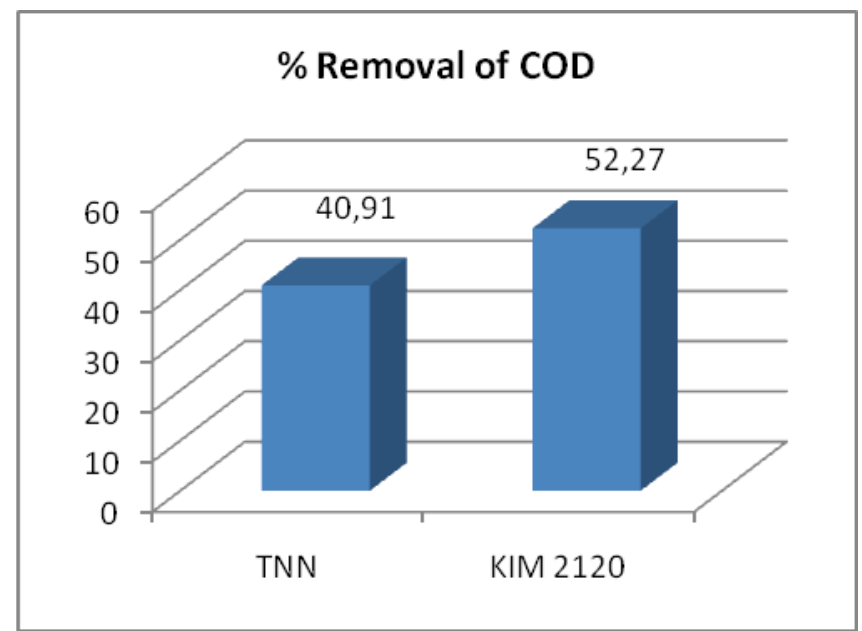

Figure.3: The effect of some concentration of Lime associated with various natural organic coagulant

The addition of different volumes of lime that allows a $\mathrm{pH}$ increase to 7, OMW are coagulated and at the same time diluted. Figure 3 shows the changes on the removal of COD and turbidity measured in the treated OMW according to the lime concentrations. ( figure 3 and 4).This result shows that lime has a very important removing capacity of the polluting matters by coagulation. In this regard, Khoufi et al., 2007 [11] and Esra Aktas et al. (2000) [12] have attributed the lime effect in the OMWW pre-treatment to the polymerization and precipitation of long chain fatty acids and on a large molecular mass polyphenols. 
The effect of coupling lime with various concentration of alginate (TNN) on OMWW treatment was studied and the results are illustred in figure 4 . When the concentration of TNN increases, COD removal and turbidity increases. Optimum $(38,39 \% ; 74,45 \%)$ COD removal and turbidity respectively was obtained after treatment by the addition of $20 \mathrm{mg} / \mathrm{l}$ alginate to the wastewater diluted (50\%). Turbidity is an index of the presence of suspended particles in the effluent (figure 5). The removal of turbidity is certainly due to the formation, destabilization and disappearance by sedimentation of these big aggregates.
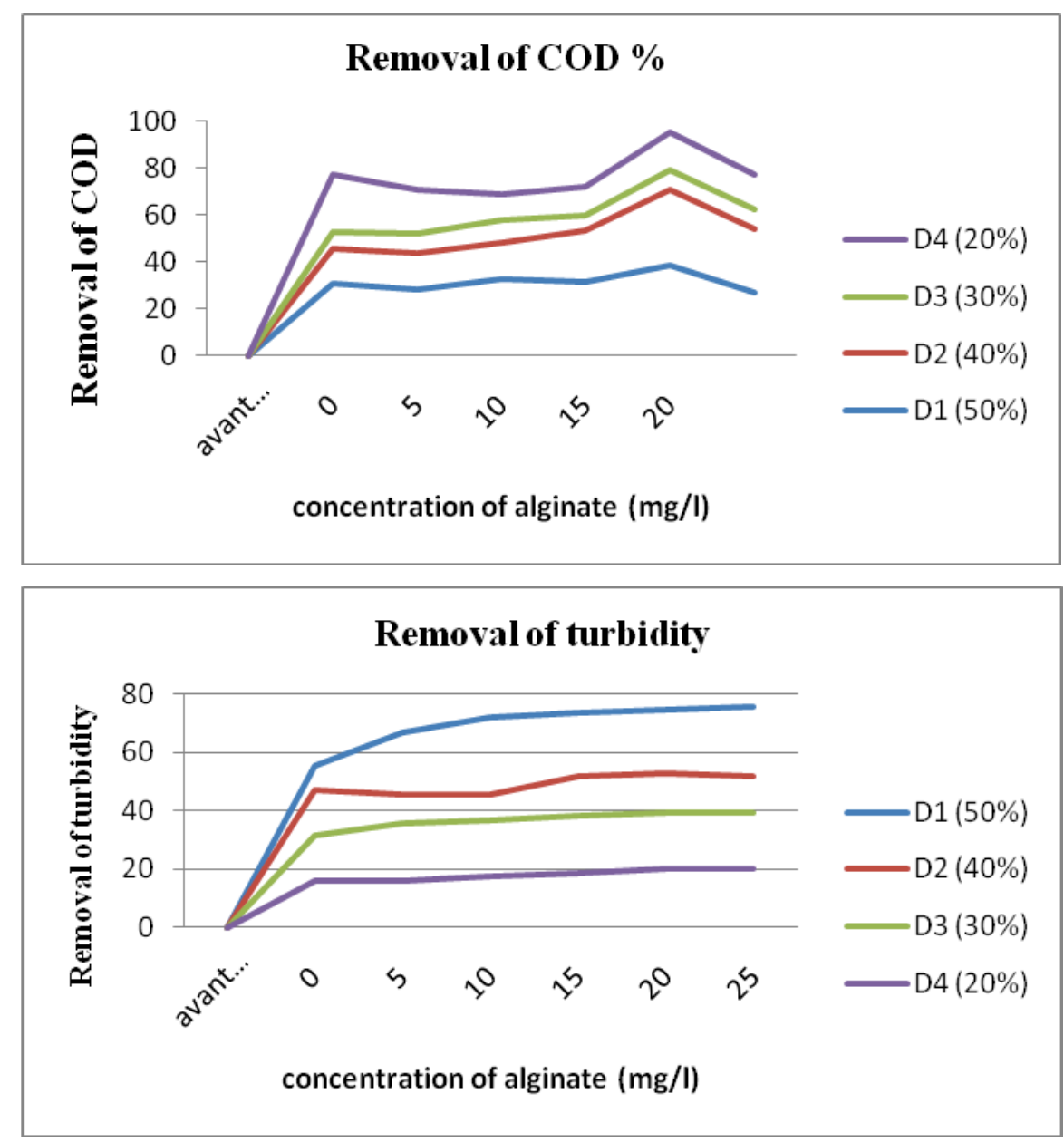

Figure4. Effect of different concentration of the alginate flocculant on the COD and turbidity removal
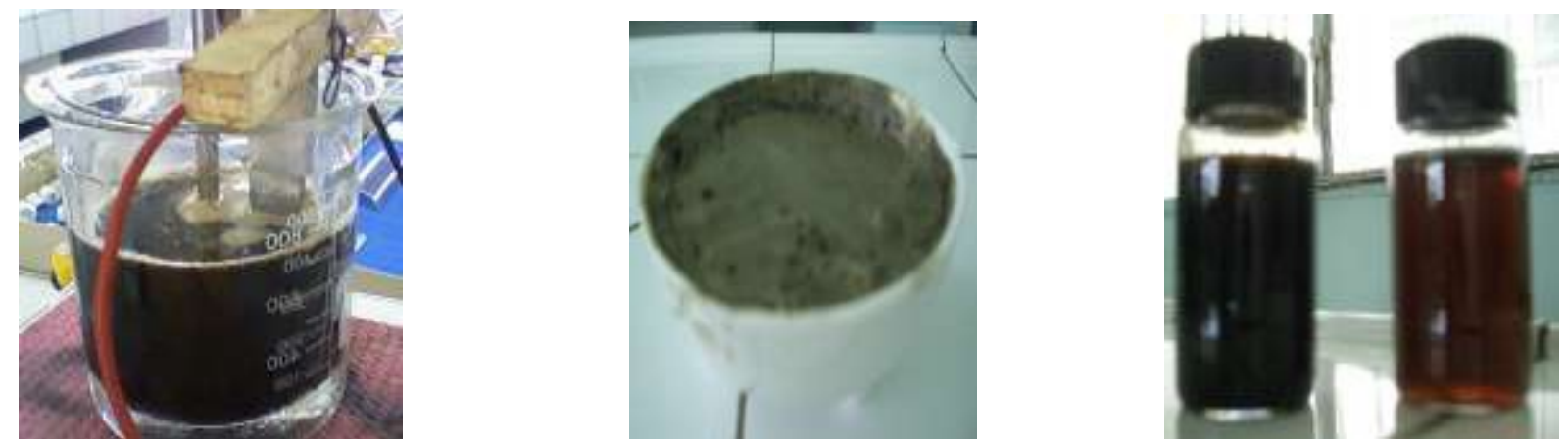


\subsection{Electrocoagulation of OMWW}

The electrocoagulation step was performed on raw OMWW and without adjustment of $\mathrm{pH}$. The effect of the electrolysis treatment on OMWW quality was characterised using mainly $\mathrm{pH}, \mathrm{COD}$, conductivity content measurement as indicators for water quality change. The characteristics of the crude and the electrocoagulated OMWW are illustrated in Table 2.

The appropriate selection of electrode material is very important. The most common electrode materials for electrocoagulation are aluminum because they are cheap, readily available and proven effective.

Table.2: Some characteristic of different parameter of $O M W W$

\begin{tabular}{lrrrrrrr}
\hline Temps (min) & 0 & 30 & 60 & 90 & 120 & 150 & 180 \\
$\mathrm{pH}$ & 4.4 & 4.49 & 4.86 & 5.01 & 5.32 & 5.7 & 6.04 \\
conductivity (ms/cm) & 21.2 & 21 & 20.4 & 20.6 & 21.2 & 21.6 & 21.9 \\
$\mathrm{COD}(\mathrm{g} \mathrm{O} / \mathrm{l})$ & 92.5 & 67.5 & 52.5 & 47.5 & 60 & 67.5 & 73.2 \\
\hline
\end{tabular}

\subsubsection{Effect of operating time on removal efficiency of $\mathrm{COD}, \mathrm{pH}$ and conductivity}

In this part of study, we have explored the effect of operating time on removal of COD, $\mathrm{pH}$ and conductivity. The initial $\mathrm{pH}$ of the OMWW was $4.4 .15 \mathrm{~V} / \mathrm{m}^{2}$ of voltage has been varied from 0 to $180 \mathrm{~min}$. The typical $\mathrm{pH}$ of OMWW is between 4 and 5.5, which allows it to be directly treated by electrocoagulation without further $\mathrm{pH}$ adjustment $[13,14,15]$. Hanafi et al., [13] and Chen et al., [15] reported that the highest removal efficiencies have been obtained in acidic medium, at $\mathrm{pH}$ values in the range 4-6. The electrocoagulation treatment using aluminum electrodes induced an increase in the $\mathrm{pH}$ value when the initial $\mathrm{pH}$ value of the olive wastewater was 4.4 which could be explained by hydrogen evolution at cathodes [24] and $\mathrm{OH}^{-}$ion accumulated in aqueous solution during the process. However, Chen et al., [25] explained this increase by the release of $\mathrm{CO}_{2}$ from wastewater owing to $\mathrm{H}_{2}$ bubble disturbance. OMW samples became visually very clear. Indeed, phenols are acids in liquids, and their removal from a solution reduces its acidity [16].

\subsubsection{COD removal dependence on time}

It has been observed that the percentage of COD-removal depends immediately on the process duration. The graphs of COD removal versus retention time demonstrate an increasing trend. So, for the 90 -min retention time, aluminum provided $56.76 \%$ COD removal The curves show that the retention time $90 \mathrm{~min}$ is optimal for the COD removal for this equipment at acidic medium ( $\mathrm{pH} \mathrm{5).} \mathrm{Within} \mathrm{the} \mathrm{electrocoagulation} \mathrm{cell} \mathrm{is} \mathrm{related} \mathrm{to} \mathrm{the} \mathrm{current}$ flow, using Faraday's law: $\mathrm{m}=\mathrm{ItM} / \mathrm{zF}$ [8] where $\mathrm{I}$ is the current intensity, $\mathrm{t}$ is the time, $\mathrm{M}$ is the molecular weight of aluminium ( $\mathrm{g}$ mol-1), $\mathrm{z}$ is the number of electrons transferred in the 
reaction $(=3)$ and $\mathrm{F}$ is the Faraday's constant $(96,486 \mathrm{Cmol}-1)$. The efficiency of COD removal depended on the quantity of hydroxide flocs, this behaviour may be due to generate significant amount of oxidized aluminium, resulting in a greater amount of precipitate for the removal of colloidal particulates and the destabilization of emulsion [17].

Because OMW are also highly saline (electric conductivity $21.2 \mathrm{mS} / \mathrm{cm}$ ), due to the salting practiced to preserve olives during trituration, there was no need to add any supporting electrolyte. The COD decrease can be essentially correlated with the decrease of conductivity of the solutions. The decrease of conductivity was explained bay decrease electrolysis voltage [18].

\section{CONCLUSION}

According to the physico-chemical study we can say that coagulation is one the most effective methods to remove organic matter and suspended colloidal. And electrocoagulation proved effective in eliminating pollutants in discharges from the olive industry. From the results obtained in this work, we can conclude that: $\varpi$ The coagulation-flocculation tests showed that application of lime with alginate at a dose of $2 \mathrm{~g} / \mathrm{L}$ at neutral $\mathrm{pH}$ can eliminate $41 \%$ of COD, while the application of lime with a dose of Kim $21201 \mathrm{~g} / 100 \mathrm{ml}$ allows eliminate $38-52 \%$ of the COD. The electrocoagulation process has reduced $49 \%$ of chemical oxygen demand oxygen, with a voltage of $15 \mathrm{~V}$ for 90 minutes.

\section{REFERENCES}

[1] Tsiolpas .A, Dimou.D, Inconomou.D, Angelis.G, 2002, Phenolic removal in olive mill wastewater by strains of Pleurotus spp. In respect to thei phenol oxidase (laccase) activity, Bioressour. Technol .84, 251-257.

[2] Erguder.T.H, Guven.E, Demirer.G.N, 2000, Aerobic treatment of olive mill wastes in batch reactors, Process Biochem, 36, 243-248.

[3] Aragon .J.M, 2000, Improvements of treatment and validation of liquid-solid waste from the two phase olive oil extraction project improlive annex, FAIR CT96 1420 final report

[4] Obirais.J, Beddioui.F, NYOKONG.T, 2005, Electro-oxidation of phenol and its derivatives on poly- $\mathrm{Ni}(\mathrm{OH}) \mathrm{TPhPyPc}$ modified vitreous carbon electrodes , J.Electroanal.Chem, 576, 2, 323-332.

[5] Loumici.H, Aiouechre.F, Belhocine.D, Driouiche.M, Pauss.A, Mameri.N, 2004, Mechanism of phenol adsorption onto electroactivated carbon granules, Water Res, 38, 1, 218-224

[6] Innan.H, Dimoglo.A, Simsek.H, Karpuzcu.M, 2004? Olive oil mill wastewater treatment by means of electro-coagulation, Sep.Purif.technol, 36,1, 23-31.

[7] Koparal.A.S, Bakir.Ogutveren.O, 2002? Removal of nitrate from water by electroreduction and electrocoagultation, .Hazard.Mater, B89, 83-94.

[8] Bakir.Ogutveren.O, Koparal.S, 1997, Electrcoagulation for oil-water emulsion treatment, JEnviron.Sci.Health part A-Environ.Sc.Eng.Tox.Hazard.Subst.Control, 32, 9-10, 2507-2520

[9] M. Kobya, O.T. Can, M. Bayramoglu, Treatment of textile wastewaters by electrocoagulation using iron and aluminum electrodes, J. Hazard. Mater. 100 (2003) 163178.

[10] M.Y.A. Mollah, P. Morkovsky, J.A.G. Gomes, M. Kasmez, J. Parga, D.L. Cocke, Fundamentals, present and future perspectives of electrocoagulation, J. Hazard. Mater. 114 (2004) 199-210.

[11] Khoufi.S, Feki.F, Sayadi.S, 2007, Detoxification of olive mill wastewater by electrocoagulation and sedimentation processes, Journal of Hazardous Materials 142 58-67. 
[12] Esra S. Et Al., 2000. Characterization and lime treatment of olive mill wastewater. Technical note, 35, 2336-2340.

[13] Hanafi.F, Assobeih.O, Mountadar.M, 2010, Detoxification and discoloration of Moroccan olive mill wastewater by electrocoagulation, Journal of Hazardous Materials 174 807-812.

[14] Vik.E.A, Carlson.D.A, Eikum.A.S, E.T.1984, Gjessing, Electrocoagulation of potable water, Water Res. 18, 1355-1360.

[15] Chen.G.H, Chen.X.M, Yue.P.L, 2000 ?Electrocoagulation and electroflotation of restaurant wastewater, J. Environ. Eng. ASCE 126, 858-863.

[16] Khoufi. S., Et A1., 2007, Detoxification of olive mill wastewater by electrocoagulation and sedimentation processes Journal of Hazardous Materials 142 , 58-67

[17] Tir.M, Moulai-Mostefa.N, 2008,Optimization of oil removal from oily wastewater by electrocoagulation using response surface method, Journal of Hazardous Materials $158,107-$ 115

[18] Mouedhen.G, Feki.M, De Petris Wery.M, . Ayedi.H.F, 2008, Behavior of aluminum electrodes in electrocoagulation process, Journal of Hazardous Materials 150 124-135 